\title{
Earthquake Forecast for the Wasatch Front Region of the Intermountain West
}

The Working Group on Utah Earthquake Probabilities (WGUEP) has assessed the probability of large earthquakes in the Wasatch Front region. There is a 43 percent probability of one or more magnitude (M) 6.75 or greater earthquakes and a 57 percent probability of one or more M6.0 or greater earthquakes in the region in the next 50 years. These results highlight the threat of large earthquakes in the region.

The spectacular relief of the Wasatch Front is the product of earthquake-generating fault movement. In this region, large earthquakes are likely to occur on faults that extend along the base of mountain ranges such as the Wasatch Range. The Wasatch fault zone is the longest, most active, and most hazardous fault in the region. Movement on this fault has created valleys, like the Salt Lake and Utah Valleys, which contain the modern Wasatch Front urban corridor. The Wasatch fault zone borders and in some places crosses through this corridor, which is home to nearly 80 percent of Utah's population of 3 million and more than 75 percent of Utah's economy.

\section{Wasatch Front Region Earthquake Forecast}

In the first comprehensive study of its kind in the Intermountain West, the WGUEP has assessed the likelihood of large earthquakes in the Wasatch Front region (WGUEP, 2016) (fig. 1). This forecast conveys the probability of one or more earthquakes of a specified magnitude range in the region in the next 50 years, similar to how a meteorologist might describe a chance of rain within a geographic region during the next few hours. The resulting earthquake probabilities are useful for seismic hazard analyses and can help inform the development of public policies leading to effective earthquake loss-reduction efforts.

\section{Earthquake Probabilities for the Wasatch Front Region}

\begin{tabular}{lcc|} 
& $\begin{array}{c}\text { M6.0 or } \\
\text { greater }\end{array}$ & $\begin{array}{c}\text { M6.75 or } \\
\text { greater }\end{array}$ \\
\hline Wasatch fault zone & $18 \%$ & $18 \%$ \\
Oquirrh-Great Salt Lake fault zone & $7 \%$ & $6 \%$ \\
Other faults in the region $^{1}$ & $34 \%$ & $25 \%$ \\
Background earthquakes $^{\text {Wasatch Front region total }}$ & $14 \%$ & $\mathrm{NA}^{2}$ \\
\hline Wron & $57 \%$ & $43 \%$
\end{tabular}

Probabilities are for one or more earthquakes in the next 50 years (WGUEP, 2016).

${ }^{1}$ Combined probability for the 45 other faults or fault sections in the region. ${ }^{2}$ Probability not calculated for background earthquakes.

There is a 43 percent probability that the Wasatch Front region will experience at least one M6.75 or greater earthquake in the next 50 years. This total probability for the region is based on new geologic information on the timing and location of large prehistoric earthquakes on known faults in the region (fig. 2). For example, investigations of the Wasatch fault zone indicate that at least 22 large prehistoric earthquakes have ruptured parts of this fault between Brigham City and Nephi in the last 6,000 years (WGUEP, 2016). The probability of at least one M6.75 or greater earthquake on the Wasatch fault zone is 18 percent in the next 50 years. The forecast

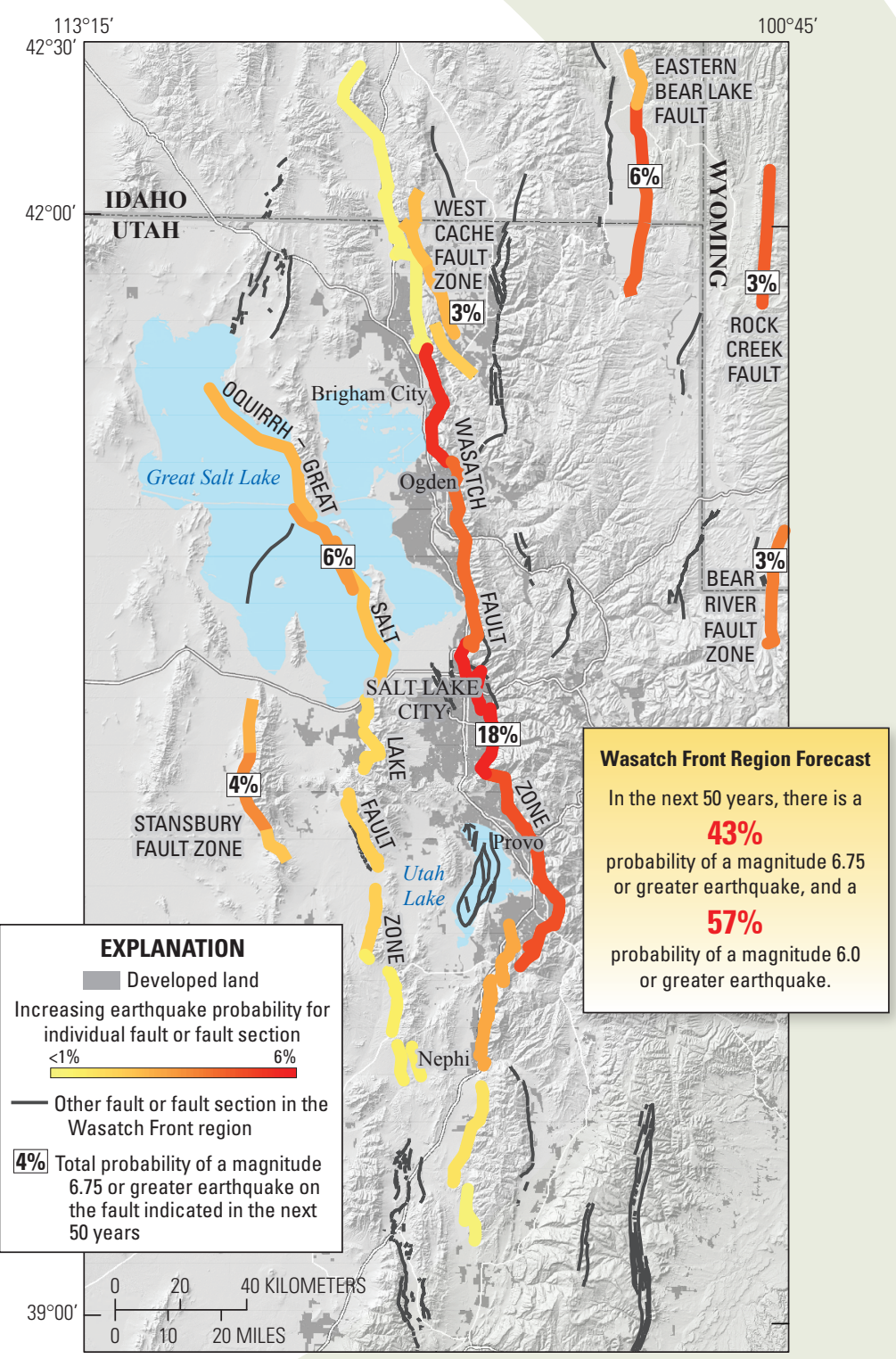

Figure 1. Magnitude 6.75 or greater earthquake probabilities may vary along faults (yellow to red fault colors), but entire fault probabilities are labeled. For example, the total probability for the entire Wasatch fault is 18 percent. Only faults with a probability of 2 percent or greater are shown. Modified from Working Group on Utah Earthquake Probabilities (2016). (\%, percent)

also incorporates information for 45 other faults or fault sections in the region that are capable of generating large earthquakes. The probability of one or more M6.75 or greater earthquakes on the other faults or fault sections is 25 percent in the next 50 years. 
There is a 57 percent probability of one or more M6.0 or greater earthquakes in the region in the next 50 years. This total earthquake probability is based on the probability of M6.0 or greater earthquakes on known faults and a reevaluation of the size of historical quakes that have occurred since the settlement of the region (fig. 2). Historical quakes are used to evaluate the potential for more moderate, M5.0 to 6.75 earthquakes in the region (known as background earthquakes) that are not associated with known faults. There is a 14 percent probability of a M6.0 or greater background earthquake in the next 50 years.

\section{Consequences of Future Earthquakes}

A large earthquake could have long-lasting effects on the population, infrastructure, and economic stability of the Wasatch Front region. For example, a large quake on the Wasatch fault zone near Salt Lake City could have an enormous impact on the region and result in 2,000 to 2,500 fatalities; 7,400 to 9,300 lifethreatening injuries; 84,000 families displaced from their homes; the disruption of lifelines like water, electricity, gas, and sewer for days to months; and a total short-term economic loss of over $\$ 33$ billion (Pankow and others, 2015). Although some faults are in undeveloped parts of the region, earthquake effects are far reaching, and a large earthquake on one of these faults could also damage and disrupt the Wasatch Front urban corridor.

These probability calculations are a reminder that the Wasatch Front region is seismically active and that large earthquakes can occur at any time. Over time, these probability calculations may be refined as new geologic and seismic data are developed and our understanding of earthquakes in the region improves. However, the threat of large earthquakes in the Wasatch Front region remains clear. As a result, individuals can take measures to be prepared and reduce their earthquake risk (Utah Seismic Safety Commission, 2008), and communities can advocate for resilient earthquake design and disaster planning.

\section{References Cited}

Pankow, Kristine; Arabasz, Walter; Carey, Robert; Christenson, Gary; Groeneveld, Josh; Maxfield, Brent; McDonough, Peter; Welliver, Barry; and Youd, T.L., 2015, Scenario for a magnitude 7.0 earthquake on the Wasatch Fault-Salt Lake City segment: Utah Chapter, Earthquake Engineering Research Institute, 53 p., accessed March 10, 2016, at https:/ussc.utah.gov/ pages/help.php?section=EERI+Salt+Lake+City + M7+Earthquake+Scenario.

Utah Seismic Safety Commission, 2008, Putting down roots in earthquake country - Your handbook for earthquakes in Utah: Utah Seismic Safety Commission, 34 p. [Also available at www.utah.gov/beready/family/ documents/puttingDownRoots.pdf.]

Working Group on Utah Earthquake Probabilities (WGUEP), 2016, Earthquake probabilities for the Wasatch Front region in Utah, Idaho, and Wyoming: Salt Lake City, Utah Geological Survey Miscellaneous Publication 16-3, 164 p., 5 appendixes. [Also available at http://geology. utah.gov/hazards/earthquakes-faults/utah-earthquake-working-groups/ utah-earthquake-probabilities/.]

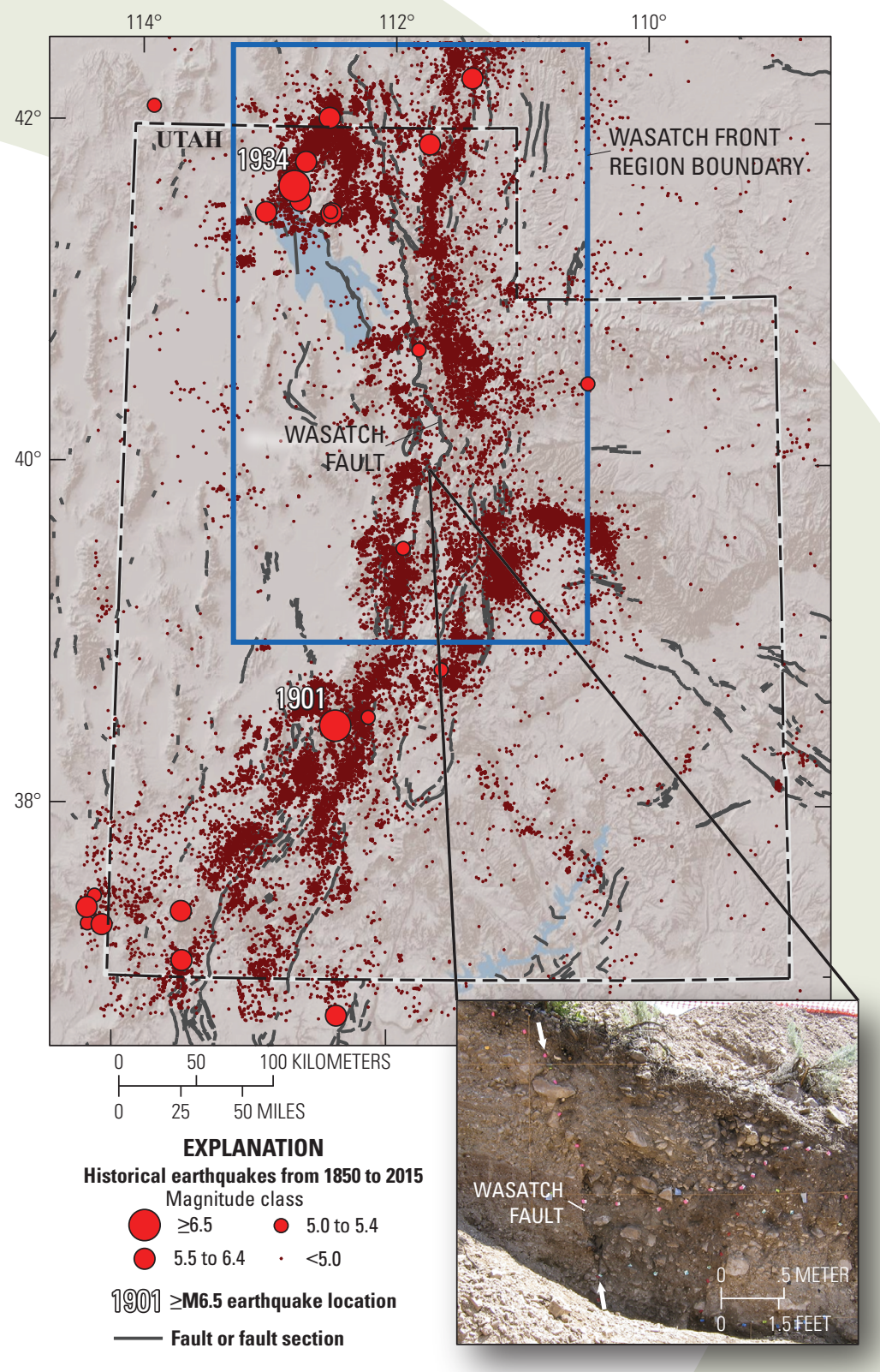

Figure 2. Historical earthquakes observed in Utah and surrounding states between 1850 and June 2015 (Working Group on Utah Earthquake Probabilities, 2016). This record is used to evaluate the potential for magnitude 5.0 to 6.75 earthquakes in the region. Inset image shows geologic investigation of a large (approximately magnitude 6.75 or greater) prehistoric earthquake on the Wasatch fault near Santaquin, Utah. Arrows indicate evidence of faulting in geologic layers exposed near the ground surface.

\section{For Further Information}

Christopher DuRoss, cduross@usgs.gov

http://geology.utah.gov/hazards/ or http://earthquake.usgs.gov/

\section{Acknowledgments}

Working Group on Utah Earthquake Probabilities (WGUEP) members include Ivan Wong (URS Corporation [URS]), William Lund (Utah Geological Survey [UGS]), Christopher DuRoss (UGS, currently U.S. Geological Survey [USGS]), Patricia Thomas (URS), Walter Arabasz (University of Utah Seismograph Stations [UUSS]), Anthony Crone (USGS), Michael Hylland (UGS), Nicolas Luco (USGS), Susan Olig (URS), James Pechmann (UUSS), Steve Personius (USGS), Mark Petersen (USGS), David Schwartz (USGS), and Robert Smith (University of Utah). The Wasatch Front region earthquake forecast was supported by the USGS National Earthquake Hazards Reduction Program, UGS, and URS. 